\title{
Applying the n-Based Approach in Management Issues of the Commercial Bank's Gains in Equity
}

\author{
${ }^{1}$ Valentina. A. Savinova, ${ }^{2}$ Marina G. Sorokina, ${ }^{3}$ Victoria V. Khmaruk, ${ }^{4}$ Maria E. Konovalova, ${ }^{5}$ Alexander \\ M. Mikhailov \\ ${ }^{1}$ Doctor of Economics, Professor of Samara State University of Economics, ${ }^{2}$ Doctor of Economics, Professor of \\ Samara National Research University, ${ }^{3}$ Candidate of Economics, Associate Professor, Samara National Research \\ University, ${ }^{4}$ Doctor of Economics, Associate Professor of Samara State University of Economics, \\ ${ }^{5}$ Doctor of Economics, Professor of Samara State University of Economics \\ E-mail: ${ }^{1}$ savinovava@yandex.ru, ${ }^{2}$ ipoteka sorokina@list.ru, ${ }^{4} \underline{\text { mkonoval@mail.ru, }}{ }^{5} \underline{\text { 2427994@mail.ru }}$
}

\section{Received: $26^{\text {th }}$ Feb 2018, Accepted 17 ${ }^{\text {th }}$ March 18, Published: $30^{\text {th }}$ April 2018}

\begin{abstract}
The importance of the issue of forming the commercial bank's equity is caused by the fact that the decision on gains in equity is based on the principle of calculation and analysis of the initial return on equity, and does not focus on methods for evaluating the prospective return on equity, taking into account its use in the bank's operating activities. The main purpose of the article is to increase the efficiency of the loan institutions' activity on the basis of a formalized approach to valuating and managing the commercial bank's equity as one of the main criteria for expanding operating activities and increasing the competitiveness of the commercial bank. The results of the research are to expand management methods of the commercial bank's equity on the basis of the optional method valuating
\end{abstract}

\section{Introduction \\ Establishing a context}

Against the backdrop of the unstable economic situation, the task of managing equity of financial organizations, including commercial banks, is especially urgent. The main goal of managing equity is to attract and maintain a sufficient amount of equity, which will expand commercial bank's operational activities and form protection against risks. It should be noted that with the low development of the banking segment in the Russian exchange market, the application of internationally accepted methods for valuing money and controlling the bank's equity is not possible. Undoubtedly, the efficiency of the commercial bank depends on the choice of methods that are used to getting gains in equity. It is necessary to develop a new tool for managing the bank's equity, taking into account the long-term development dynamics of the loan institution and investors' expectations.

This tool can be the method of real options. In practice, as a rule, Black-Scholes dynamic model is used, the most important feature of which is its ability to assess the effectiveness of adopted management strategies in terms of their impact on the return on the bank's equity, taking into account changes in financial market conditions, which definitely increases the valuation return results on equity. the return on equity, which includes elements of gain and return approaches and takes into account the dynamics of price fluctuations during the commercial bank's operating activities. Based on Black-Scholes dynamic model, the authors use the method for evaluating the effectiveness of gains in equity in two ways: 1 . capitalization due to retained earnings; 2 . the secondary issue of shares. The mechanism for choosing the capitalization method of the bank based on the return approach is proposed, which allows identifying the most effective method of getting gains in equity, and later, when managing, developing corrective actions regarding the use of equity in the commercial bank's operating activities.

Keywords: Commercial Bank, Capital, Return, Model, Option

\section{Reviewing the Literature}

Scientific literature abounds with a sufficient number of works by foreign and Russian authors, which highlight the diversity of methods for valuating and managing the bank's equity. Many foreign scholars in the field of finance have made a significant contribution to the study of the management issue of the commercial banks' equity, the methods of its formation and valuation. Among the researchers of this issue are: A. Damodaran [1], J. Sinky (2007) [2], Dahl \& Spivey (1996) [3], Ahmed, Takeda (1995) [4], Rossia, Schwaiger, Winkler (2009) [5], Glen, Camilo Mondragón-Vélez (2011) [6] and etc.

It should be noted that foreign authors valuate equity from the standpoint of its sufficiency, that is, the ability to compensate losses and avoid bankruptcy, and they do not take into account the possibility of expanding the bank's operating activities. Issues related to the development of the banking system, the study of the economic nature of banks are disclosed in the works of G.N. Beloglazova (2008) [7], L.P. Krolivetskaya [7], O. I. Lavrushin (2012) [8], G.A. Tosunyan et al. [9], Schooner \& Taylor (2010) [10].

The works of Russian scientists show the dependence of the management efficiency of the commercial bank's equity and financial results of its work, which 
in turn is inextricably linked with the stability of functioning and reliability of the banking system. The presented works illustrate methods of increasing the bank's equity, the specifics of their implementation. The methods are based on the retrospective financial analysis of the bank's activities, which does not allow us to evaluate the bank from the perspective of its prospects, related to the increase in the bank's capitalization.

The works of Morsink and Gordon (2016) [11], Zayernyuk et al. (2016) [12], Gorchakov, Alvarez (2017) [13], Anzoategui, Martínez Pería and Melecky (2010) [14], Gunter Deuber (2017) [15] are mainly devoted to the adaptation of foreign methods of valuating the bank's shares and equity to the Russian banking environment, regulatory indicators of the bank's activities, and requirements for financial reporting. Thus, the analysis of the works published on the subject of the research indicates the insufficient scientific study of the effective management of the commercial bank's equity on the basis of the formalized approach and the decision making mechanism to increase the capitalization of the bank.

\section{Establishing a Research Gap}

In the textbook of G. G. Korobova (2015) [16], the definition of the bank's equity is given as: "... the bank's property, free of obligations and which has a permanent irretrievable nature, has a clearly expressed legal basis and functional certainty, is an indispensable condition for the formation and functioning of any commercial bank, as it is a core which all the commercial bank's activities are based on from the first day of its existence" (Korobova, 2015) [16]. In the aggregate capital of the commercial bank, the bank's equity owns a small share (about 10\%), and, for comparison, in industrial organizations, this figure is in the range of 40-60\% (Lavrushin, 2012) [8].

This is due to the difference in the appointment of equity in the commercial bank and in enterprises of various fields of activity. For industrial enterprises, equity guarantees the solvency and performance of core activities, whereas for the commercial bank, equity primarily guarantees the insurance of investors and depositors' interests, at the expense of whom the commercial bank's operating activities are realized (Sorokina \& Khmaruk, 2012) [17]. It should be noted that the commercial bank's equity performs protective, operational and regulatory functions. The protective function is implemented in case of the bank's liquidation by the possibility of paying compensation to investors and depositors. By creating the asset reserve, equity allows the bank to maintain its solvency, which enables the bank to operate, regardless of the threat of losses. The main percentage of losses is covered by the current gain of the bank, and not at the expense of equity.

The allocation of own funds to purchase real estate and equipment, to create a financial reserve, in case of unforeseen losses, realizes the operational function. The regulatory function of the bank's equity is related to bodies that carry out the valuation and management of the bank's activities on the basis of normative indicators. The bank's equity adequacy ratio includes requirements for its minimum size, restrictions on assets and borrowed funds of the bank (Sorokina \& Khmaruk, 2012) [17].

Taking into account that in the modern financial market there is a need to evaluate the banking business, and some of its separate activities: deposit and loan, we can talk about the advisability of allocating a new, fourth function - valuation. The valuation function will allow valuating the return on equity, and using this valuation draw conclusions about the prospects for the banks' development, its investment attractiveness and competitiveness.

Figure 1 shows the movement of equity to reflect the functions performed by it.

The management of the bank's equity is directly related to the use of the valuation function.

The use of the valuation function enables the management of the bank to manage equity. The need of gains in equity is associated with the need to expand the scope of the bank's activities in the financial market and the development of new banking products.

We can single out two gains sources in equity: an internal source, namely reallocation of retained earnings in the bank's authorized capital and an external source, namely an additional issue of own shares. The main task of the bank's management is to determine the most optimal method of gains in equity. The optimal method is the prospective return on the bank's equity, which takes into account the possibility of increasing the bank's interest gain and profit. 


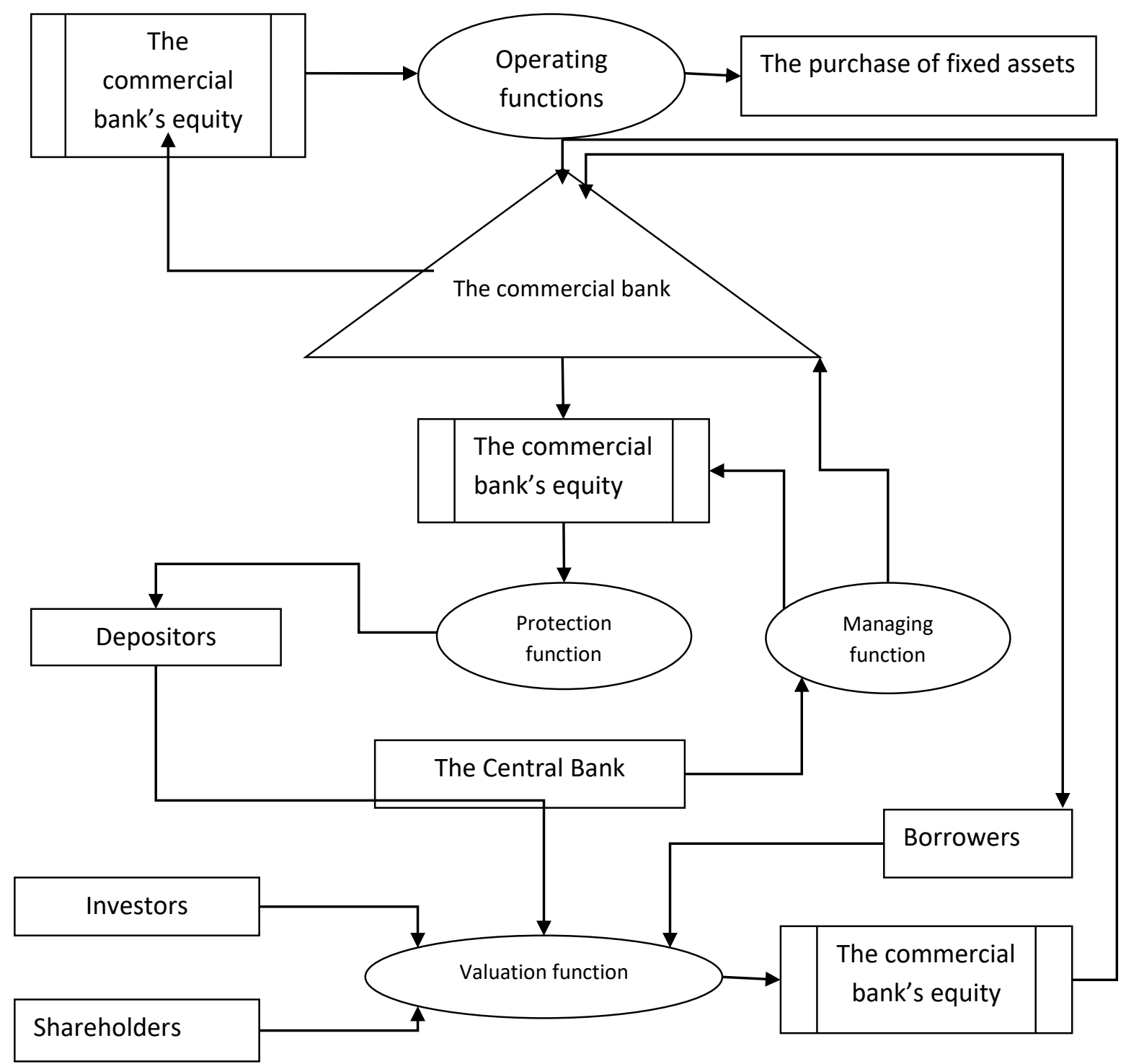

Figure 1. Reallocation of Cash Flows of the Commercial Bank's Equity in the Context of its Functions Source: Compiled by the Authors.

\section{Stating the Purpose}

The purpose of the scientific work is to develop methods for evaluating the return on the commercial bank's equity, and the mechanisms for managing it by increasing the operating efficiency of the commercial bank. The implementation of this goal involves the following tasks:

- Identify the main functions of the loan institution's equity and justify the need to use the valuation function from the position of valuating and managing the commercial bank's equity;

- Conduct the analysis of existing methods for evaluating the return on the commercial bank's equity, and propose the application of Black-Scholes dynamic model to the valuation of the bank's equity;

- Highlight the main parameters of the option model; propose the algorithm for calculating them to evaluate the return on the commercial bank's equity;

- Modify Black-Scholes dynamic model to evaluate the prospective return on the commercial bank's equity, the increase in its capitalization is due to writing off retained earnings in the bank's authorized capital;
- Develop the model of the decision-making mechanism to getting gains in the bank's equity by secondary issuing of its own shares;

- Propose the mechanism for managing the commercial bank's equity with the application of the return approach.

\section{Methods of Research}

During the research, the formalization method was used to evaluate the return on the bank's equity with the use of Black-Scholes dynamic model, as well as the description of parameters of the option model and the algorithm for calculating them. To forecast the operating gain from the use of cash resources of the bank's equity, functional analysis was used. Dynamic analysis was used in the process of developing a mechanism for managing the bank's equity. The development of the model to evaluate the return on equity and the decision-making mechanism includes methods of economic-mathematical modeling and forecasting. The theoretical basis for the study is the classical valuation theory of the market return on property objects, as well as a comparison and critical 
analysis of the works of Russian and foreign authors on the topic of the research. The experimental base of the research was based on findings of audits of major Russian banks, financial statements of a number of commercial banks and published annual reports.

\section{Results}

Certain limitations in evaluating the banking business and equity in particular arise when using conventional valuation approaches. The disadvantage of using the return approach is that if the indicator of the company's return is negative, valuated by the method of net assets, share quotes on the exchange market can have a high price. The disadvantage of using the gain approach is the underestimation of the return of companies operating under conditions of instability (Sorokina \& Khmaruk, 2012) [17].

The mentioned shortcomings point to the need to create new methods for evaluating the return on equity, which can take into account the dynamics of the commercial bank's development and investors' expectations. The real option method (ROV-method from English - Real Options Valuation) refers to a number of similar methods. Black-Scholes model is used in the real options method in practice. This method makes it possible to evaluate the rationality of strategies adopted by the management from the point of view of their influence on the bank's equity with active dynamics of external factors. The results of valuating the return of equity are more objective in this case. The return on equity in the proposed model is represented as the return on a call option, which consists of the company's assets and liabilities. The broadest application of Black-Scholes dynamic model can be obtained in evaluating the return of such companies, in which the returns on assets and liabilities are comparable in magnitude and dynamic over time. In the banking sector, assets and liabilities are close in importance. Based on this, it can be said that the option method can be used to evaluate the return on the commercial bank's equity and is expressed as follows:

$$
\mathrm{Ce}=\mathrm{S}_{\mathrm{e}}^{-\delta \mathrm{t}} \cdot \mathrm{N}\left(\mathrm{d}_{1}\right)-X_{e}^{-r t} \cdot N\left(d_{2}\right),
$$

where $\mathrm{Ce}$ - the return on the commercial bank's equity;

$\mathrm{N}(\mathrm{d})$ - the normal allocation function, where $\mathrm{d}$ is determined by:

$$
d_{1}=\frac{\ln \frac{S}{X}+\left(r+\frac{\sigma^{2}}{2}\right) \cdot t}{\sqrt{\sigma^{2} \cdot t}} d_{2}=d_{1}-\sqrt{\sigma^{2} \cdot t}
$$

where $\mathrm{S}-$ the current return on the bank's assets; $\mathrm{X}$ - the nominal return on the bank's liabilities; $\mathrm{r}$ - the risk-free investment rate;

$\delta$ - the dividend gain rate.

To calculate the return on the bank's equity by model (1), it is necessary to adapt the model parameters. The risk-free investment rate (r) has to be calculated, as a weighted average by the volume of the bank's raised funds:

$$
r=\frac{\sum_{i=1}^{m} x_{i} \cdot r_{i}}{\sum_{i=1}^{m} x_{i}}
$$

where $r_{i}$ - the interest rate of the $i-$ th customer - a commercial bank depositor.

The indicator $\sigma$ - is an important element of the model and is calculated as the standard deviation of return on assets of the commercial bank:

$$
\text { Var }=\sigma^{2}=\frac{1}{n} \sum_{j=1}^{n}\left(\delta_{j}-\bar{\delta}\right)^{2}
$$

where $\delta_{j}$ - the interest rate of the $\mathrm{j}$-th type of the bank's loan operations;

$\bar{\delta}$ - the weighted average interest rate of the commercial bank's loan portfolio;

$\mathrm{n}-$ the number of loan investments.

The debt duration $t$ is an indicator that significantly influences the definition of the total return on the bank's equity.

We will calculate the duration as the weighted average maturity of the bank's deposit portfolio and loan portfolio.

The maturity of the deposit portfolio $\left(t_{d}\right)$ is determined from the following equation:

$$
t_{d}=\frac{\sum_{i=1}^{m} x_{i} \cdot t_{i}}{\sum_{i=1}^{m} x_{i}},
$$

where $t_{i}-$ is the deposit period of the $\mathrm{i}$-th customer deposit.

Similarly, the indicator $t_{1}-$ is defined as the weighted average term of the loan portfolio.

$$
t_{l}=\frac{\sum_{j=1}^{m} S_{j} \cdot t_{j}}{\sum_{j=1}^{m} S_{j}}
$$

where $t_{j}-$ is the maturity of the loan of the $\mathrm{j}$-th customer-borrower.

As a rule, in banking practice, the maturity of the deposit and loan portfolio is not coordinated in time. This is due to a low stabilization of the resource, and a large need for long-term loans from borrowers. The use of only one time indicator in the model is incorrect because it does not take into account this aspect. Hence it becomes necessary to focus on the return on the indicator with greater maturity: 


$$
t=\max \left(t_{\mathrm{d}} ; t_{\mathrm{l}}\right)
$$

The indicator of the dividend gain $(\delta)$ is reduced to the definition of the weighted average interest rate on the bank's loan portfolio:

$$
\delta=\frac{\sum_{j=1}^{n} S_{j} \cdot \delta_{j}}{\sum_{j=1}^{n} S_{j}},
$$

where $\delta_{\mathrm{j}}$ - the interest rate of the loan $S_{\mathrm{j}}$

The valuation of equity according to Black-Scholes model can be calculated both from the accumulated assets ( $\mathrm{S}$ ) and accrued liabilities (X) of the bank. In this case, instead of the profitability return on the commercial bank's operations, a risk-free interest rate is possible, but the model, that uses the current return on the bank's loan operations and borrowed funds, has the highest valuation accuracy, and the degree characterizes the dynamics of these cash flows accumulation in time. Calculation of accrued liabilities is made with a positive interest rate for deposit (r) and loan $(\delta)$.

The main advantage of using the option approach when evaluating the commercial bank's equity is especially relevant with the following factors:

1. High uncertainty in the indicator of future changes in the market situation;

2. High degree of influence of the financial market conjuncture on loan operations;

3. The standard DCF technique gives a valuation close to zero (Sorokina \& Khmaruk, 2012) [17].

The proposed method does not require a full analysis of the financial market, it gives an opportunity to reveal changes in the return on the bank's equity in dynamics, to find causal relationships and to make effective management decisions.

Consider the basic parameters of Black-Scholes model and carry out their modification in the case when gains in the bank's equity are at the expense of the bank's internal sources - writing-off of a portion of undistributed profits on the commercial bank's equity. To expand their activities, commercial banks often use the most acceptable form of their own financing reinvest part of the return on equity. The main advantage of this form of capital expansion is that there is no increase in the number of owners, and the profitability of shares does not decrease due to the increase in their number in circulation.

The net profit, which remains after the payment of taxes, can be used by the bank's management to ensure the proper level of dividend payments to shareholders and the necessary financing of the bank's activities (Korobova, 2015) [16].

Consider the most significant indicator of the bank's return on effort - ROE. Rate on return includes the following components:
$R O E=R O A \cdot \mathrm{CM} \cdot \mathrm{PM}$

Asset performance:

$$
R O A=\frac{\mathrm{I}}{S} \text {, }
$$

where S- loan investments of the commercial bank; $\mathrm{I}$ - the interest and non-interest gain of the commercial bank.

Capital multiplier:

$$
\mathrm{CM}=\frac{s}{\mathrm{E}}
$$

This indicator represents the degree of asset coverage at the expense of equity. It is obvious that with gains in the numerical return on the capital multiplier, the risk of bank losses increases.
Profit margin: $\mathrm{PM}=\frac{\mathrm{NP}}{\mathrm{I}}$

As can be seen from equation (9), not always the gain in the capitalization of the bank contributes to the gain in the return on equity.

The higher the share of retained profit, the higher the return on the profit margin, but the lower the return on the capital multiplier. Gains in equity are advisable if at the same time the bank increases the volume of active operations due to gains in the volume of raised funds and, as a result, raises interest gain (Limitovsky, 2014) [18]. This possibility of using equity will lead to gains in profitability of the commercial bank's equity. It is known that the net profit cannot be fully allocated to replenish equity, as part of the funds goes to pay dividends. The formation of the bank's dividend policy is an important issue that requires separate consideration.

When the volume of distributed profit increases to replenish dividend payments, the growth rate of the bank's profit decreases, which hinders the gain in the volume of assets that generate revenue, and so the bank's risk of bankruptcy increases. At the same time, the decrease in the volume of profit allocation among shareholders leads to the decrease in the exchange return on shares. This entails the decrease in the return on the bank's equity. It is necessary to choose the optimal dividend policy of the bank, which will allow saving existing shareholders and attracting new ones. This is possible in the case when the return on equity is at least equal to the gain of other investments with a similar degree of risk.

So $\lambda$ - is the share of dividend payments in the bank's net profit, $\mathrm{p}-$ is the growth of profit, then the rate of profit going to replenish equity is the following:

$$
q=(1-\lambda)
$$

Then, taking (13) into account, (9) takes the following form:

$$
R O E=R O A \cdot \mathrm{CM} \cdot \mathrm{PM} \cdot(1+q)
$$

It is obvious that the return on ROE increases with a positive return on $\mathrm{q}$ and allocation of the released resource in assets that generate interest gain. $\mathrm{q}<0$ is 
possible if there are preference shares in the equity structure and a negative or too small return on the bank's net profit, so in this case ROE will decrease. In case of gains in equity by allocating part of the profit in the commercial bank's assets, you can expand the return on $\mathrm{S}$ in accordance with the structure of assets, then:

$S=S_{\text {ia }}+S_{\mathrm{li}}+S_{\mathrm{ai}}+S_{\mathrm{c}}$,

where $\mathrm{S}_{\mathrm{ia}}$-investment assets; $\mathrm{S}_{\mathrm{li}}-$ loan investments;

$\mathrm{S}_{\mathrm{ai}}$ - the amount of immobilization; $\mathrm{S}_{\mathrm{c}}-$ cash. Note that investment assets and loan investments refer to assets that generate the interest gain. In this regard, it is advisable to group assets into interest gain $\left(\mathrm{S}_{\mathrm{ia}}, \mathrm{S}_{\mathrm{li}}\right)$ and non-interest gain assets $\left(\mathrm{S}_{\mathrm{ai}}, \mathrm{S}_{\mathrm{c}}\right)$. Then:

$S=S_{\mathrm{l}}+S_{\mathrm{c}}$,

where $S_{1}$-the aggregate amount of investments and loan investments of the bank;

Table 1. Calculation of Indicators and Model Parameters
$\mathrm{S}_{\mathrm{c}}-$ the aggregate amount of the bank's cash and immobilization assets.

Gains in the bank's equity, as a rule, leads to gains in the bank's raised funds $(\mathrm{X})$. What affects the return on equity. Black-Scholes model allows valuating the mechanism of asset allocation and revealing the impact on the return on equity of the bank's deposit base in aggregate.

Calculation of the prospective return on equity by Black-Scholes model will look like:

$R(t)=\left(S_{1} \cdot e^{\delta t}+S_{\mathrm{c}}\right)(1+R O E) \cdot N\left(d_{1}\right)-X \cdot$ $e^{r_{\mathrm{ef}} t} \cdot N\left(d_{2}\right) \quad(17)$

Table 1 provides an example of calculating key performance indicators of the commercial bank and parameters of the option model for evaluating the prospective return on the commercial bank's equity, Petro commerce, taking into account the allocation of part of the profit into the authorized capital of the bank.

\begin{tabular}{|c|c|c|}
\hline $\begin{array}{c}\text { Financial Performance Indicators of } \\
\text { the Commercial Bank }\end{array}$ & Description & Return \\
\hline $\mathrm{I}_{\mathrm{g}}$ & Interest gain & 15160623 \\
\hline $\mathrm{N}_{\mathrm{ig}}$ & Non-interest gain & 3118767 \\
\hline $\mathrm{IO}$ & Interest outlay & 8351212 \\
\hline NP & Net profit & 97677 \\
\hline$\lambda$ & $\begin{array}{l}\text { Share of dividend payments in net profit } \\
\text { of the bank }\end{array}$ & 0,3 \\
\hline $\mathrm{p}$ & Increment in profit & 0,5695 \\
\hline $\mathrm{q}$ & Rate of return on equity replenishment & 0,7 \\
\hline$S$ & Assets & 175349924 \\
\hline$t_{1}$ & Average maturity of the loan portfolio & 3,84 years \\
\hline$t_{\mathrm{d}}$ & Average maturity of the deposit portfolio & 1,42 years \\
\hline \multicolumn{3}{|c|}{ Parameters of Black-Scholes Model } \\
\hline \multicolumn{2}{|l|}{$S_{1}$} & 143558819 \\
\hline \multicolumn{2}{|l|}{$S_{\mathrm{c}}$} & 31791105 \\
\hline \multicolumn{2}{|l|}{$\delta$} & 0,105 \\
\hline \multicolumn{2}{|l|}{$\mathrm{t}$} & 3,84 years \\
\hline \multicolumn{2}{|l|}{$\mathrm{X}$} & 150568890 \\
\hline \multicolumn{2}{|l|}{$r_{\text {ef }}$} & 0,0659 \\
\hline \multicolumn{2}{|l|}{$\mathrm{ROE}$} & 0,64 \\
\hline
\end{tabular}

Source: Calculated based on Annual Financial Statements of OJSC Bank "Petrocommerce" in 2011. On October 30, 2013, Petrocommerce Bank was sold to Otkrytiye Corporation, the Bank was estimated at 19.5 Billion Rubles at the Sale.

Substituting parameters values (Table 1) into equation (17), we determine the return on equity of Petrocommerce Bank (Table 2). Similarly, the calculation of parameters and the prospective return on the commercial banks' equity - VTB Bank and Rosbank (Table 2) were carried out. 
Table 2. Comparative Valuation of the Prospective Return on Gains in the Commercial Bank's Equity, Due to Internal Sources

\begin{tabular}{|l|c|}
\hline Name of the Commercial Bank & Return on Equity C(t) \\
\hline Petrocommerce bank & 102513831 thousand rubles \\
\hline VTB Bank & 2300144446 thousand rubles \\
\hline Rosbank & 821500,4575 thousand rubles \\
\hline
\end{tabular}

Source: Parameters of Black-Scholes Model are calculated based on the data of the Annual Financial Statements for VTB Bank, Rosbank in 2015; the Prospective Return on Equity is calculated by the Formula (17).

The authors consider the possibility of the secondary issue of own shares as a variant of gains in the bank's equity.

Additional (secondary) issue of shares leads to gains in several components of the bank's equity. There are gains in the authorized capital, share premium value and reserve capital.

The bank manager needs to find a relationship between the efficiency of the commercial bank's activity and the market price trend of the share in order to take a decision on the additional issue of shares. The important point is to predict the future share value, that is, its price target. The authors consider financial indicators that affect the change in the market price of the share:

EPS - profit per share.

$E P S=\frac{\mathrm{NP}}{Q}$,

where $\mathrm{NP}-$ net profit of the bank;

Q- the number of shares in circulation.

$\mathrm{PR}$ - the dividend gain. This return determines the share of the commercial bank's profit, which is used to pay dividends per share:

$$
P R=\frac{\text { Div }}{E P S},
$$

where Div - the paid dividend per common share. $\frac{P}{E}-$ the market share value to the share value for the last year.

$$
\frac{P}{E}=\frac{\mathrm{MV}}{E P S_{i}},
$$

where $\mathrm{MV}_{i}$ - the market share value.

$\frac{P}{S}$ - the ratio of the share value to the interest gain per share:

$$
\frac{P}{S}=\frac{P}{S P S}
$$

The most successful companies are those whose ratio (21) is less than one.

In order to make a decision on getting gains in equity through additional share issue, it is necessary to valuate the following relations: $\frac{P}{B}=\frac{P \cdot Q}{\mathrm{E}} ; \frac{P}{S}=\frac{P \cdot Q}{\mathrm{Ig}} ; \quad \frac{P}{E}=\frac{P \cdot Q}{\mathrm{NP}}$

It can be seen that the numerator of these indicators is the capitalization of the bank. From the presented it is visible, that with the growth of shares quantity in circulation $(\mathrm{Q})$ the capitalization of the company will grow. In this regard, the market will try to balance the capitalization of the bank, thereby reducing the market share value $(\mathrm{P})$. On the other hand, with gains in equity, it becomes possible to increase operating gain, which entails gains in net profit of the bank, and, hence, in the share of dividend payments. This suggests that the shares are becoming more attractive to investors. The increase in the demand for shares is accompanied by gains in the market value. $I_{i}$

- interest gain of the commercial bank can be represented as:

$$
\mathrm{I}_{\mathrm{g}}=S_{k} \cdot \delta \cdot t-X \cdot r \cdot t
$$

Equation (23) shows that the amount of interest gain can be influenced by a change in interest rates $(\delta, \mathrm{r})$ with a fixed amount of cash resources involved in loans, or a change in the amount of cash resources $\left(\mathrm{S}_{\mathrm{l}}\right)$ involved in loans at fixed rates and volumes, and, finally, by the decrease in the share of non-interest gain in cash resources $\left(S_{c}\right)$ (Sorokina \& Khmaruk, 2011) [21]. It should be noted that with the increase in interest rates on loans, there is a risk of losing borrowers, reducing the demand for loans. The gain of the bank will decrease noticeably. With a lower interest rate on deposits, there is a risk of reducing the number of depositors, as the investment attractiveness of the bank deposit will decrease.

The indicator of the bank's effective management and the choice of the correct way of financial policy is the growth of gains relative to the operating gain. The favorable indicator is the growth rates of gains exceeding the $\frac{P}{E}$ index and outstripping the growth rate of the operating gain. In this case, we can conclude that the gain is due to changes in the structure of the deposit-loan portfolio, and not only through the growth of loan investments.

All of the above illustrates the importance of making the right decision by the bank's management, which needs not only to calculate indicators of the future operating gain and the bank's forecast gain, but also to calculate the price target of the share, i.e. its estimated future price in the market.

Fundamental analysis shows that the change in the share price corresponds to the dynamics of the operating gain. Consequently, the $\frac{P}{E}$ ratio is the valuation of the share by investors, and it changes in accordance with the rate of change in the bank's operating gain. Then the future the $\frac{P}{E}$ ratio is defined as: 


$$
\frac{P}{E_{(t)}}=\frac{P}{E} \cdot \frac{\mathrm{Ig}_{(t)}}{\mathrm{Ig}_{(t-1)}}
$$

The estimated market return of the share after the issue:

$$
P_{t}=\frac{P}{E} \cdot \frac{\mathrm{I}_{(t)}}{\mathrm{I}_{(t-1)}} \cdot E P S_{\text {aggr }}
$$

The forecast return of $\mathrm{EPS}_{\mathrm{aggr}}$ is determined in accordance with the dynamics of EPS in the past. When speaking about determining the forecast returns of indicators, it is necessary to take into account the possible risk. In this case, it is necessary to take into account external risks, since the securities market is very dynamic, dependent on the general market conditions and is extremely susceptible to external changes. Assume that the n-return of risk, including both internal and external factors, then the future return of the stock is determined by:

$P=\frac{P_{(t-1)}}{E} \cdot \frac{\mathrm{I}_{t}}{\mathrm{I}_{(t-1)}} \cdot E P S_{\text {aggr }} \cdot(1 \pm n)$

Taking into account the above, the basic indicators of Black-Scholes model are determined in the case of valuation and management of equity with the additional issue of bank shares.

The return of $\mathrm{S}$ characterizes the market capitalization of the bank:

$$
S=P \cdot Q
$$

With the growth of the bank's net profit, the volume of dividend payments grows, and, conversely, on the contrary: when the volume of gains decreases, the volume of dividend payment decreases. In this connection, the rate of dividend gain of shares can be taken as the discount rate. Then Black-Scholes model will take the form:

$R(t)=P \cdot Q \cdot e^{R O E \cdot t} \cdot N\left(d_{1}\right)-X \cdot e^{r t} \cdot N\left(d_{2}\right)$

Substituting expression (26) into equation (28), instead of the predicted return on the share $\mathrm{P}$, we will get:

$$
\begin{aligned}
& R(t)=\frac{P(t-1)}{E} \cdot \frac{\mathrm{Ig}_{t}}{\mathrm{Ig}_{(t-1)}} \cdot E P S_{\mathrm{aggr}} \cdot(1 \pm n) \cdot Q \cdot \\
& e^{R O E \cdot t} \cdot N\left(\mathrm{~d}_{1}\right)-\mathrm{X} \cdot \mathrm{e}^{\mathrm{rt}} \cdot \mathrm{N}\left(\mathrm{d}_{2}\right) \\
& \frac{\mathrm{P}}{\mathrm{B}}=\frac{\mathrm{P} \cdot \mathrm{Q}}{\mathrm{E}}<3,5 \quad \frac{\mathrm{P}}{\mathrm{C}}=\frac{\mathrm{P} \cdot \mathrm{Q}}{\mathrm{Ig}_{\mathrm{g}}}<1 \quad \mathrm{ROE}=\frac{\mathrm{NP}}{\mathrm{E}}> \\
& 0,15 \quad \frac{\mathrm{NP}}{\mathrm{NP}_{(\mathrm{t}-1)}}>\frac{\mathrm{Ig}_{(\mathrm{t})}}{\mathrm{I}_{(\mathrm{t}-1)}} \quad \text { (29) }
\end{aligned}
$$

It should be noted that by reallocating cash flows for various types of active operations, you can get a different return on equity. The proposed model of the decision-making mechanism, presented in the form of a system of equations (29), allows the bank manager to identify the dynamics of changes in the return on equity at any point in time and gives the opportunity to promptly adjust the unsatisfactory indicators.

Table 3 provides an example of calculating key performance indicators of the commercial bank and parameters of the option model for evaluating the prospective return on the commercial bank's equity, Petrocommerce, with gains in equity through the additional issue of its own shares.

Table 3. Calculation of Indicators and Model Parameters

\begin{tabular}{|c|c|}
\hline \multicolumn{2}{|c|}{ Parameters of Black-Scholes Model for Petrocommerce Bank } \\
\hline $\mathrm{P}_{(\mathrm{t}-1)}$ & 8,5 rubles \\
\hline $\mathrm{E}$ & 0,195 \\
\hline $\mathrm{EPS}_{\mathrm{aggr}}$ & 0,16 \\
\hline $\mathrm{t}$ & 3,84 years \\
\hline $\mathrm{n}$ & 0,14 \\
\hline $\mathrm{Q}$ & 800000000 \\
\hline $\mathrm{X}$ & 150568890 thousand rubles \\
\hline $\mathrm{r}_{\mathrm{ef}}$ & 0,0659 \\
\hline $\mathrm{ROE}$ & 1,22 \\
\hline
\end{tabular}

Source: calculated based on annual financial statements of OJSC Bank "Petrocommerce" in 2011.

Substituting parameters values (Table 1) into equation (17), we determine the return on equity of Petrocommerce Bank (Table 4). Similarly, the calculation of parameters and the prospective return on the commercial banks' equity - VTB Bank and Rosbank (Table 4) were carried out.

Table 4. Comparative Table of the Return on the Banks' Equity due to Additional Issue of Own Shares

\begin{tabular}{|l|c|}
\hline \multicolumn{1}{|c|}{ Name of the Commercial Bank } & Return on Equity C (t) Thousand Rubles \\
\hline Petrocommercebank & 344085725 \\
\hline VTB Bank & 3794220000000 \\
\hline Rosbank & 2469190000000 \\
\hline
\end{tabular}

Source: Parameters of Black-Scholes Model are calculated based on the data of the Annual Financial Statements for VTB Bank, Rosbank in 2015; the Prospective Return on Equity is calculated by the Model $(28,29)$. 


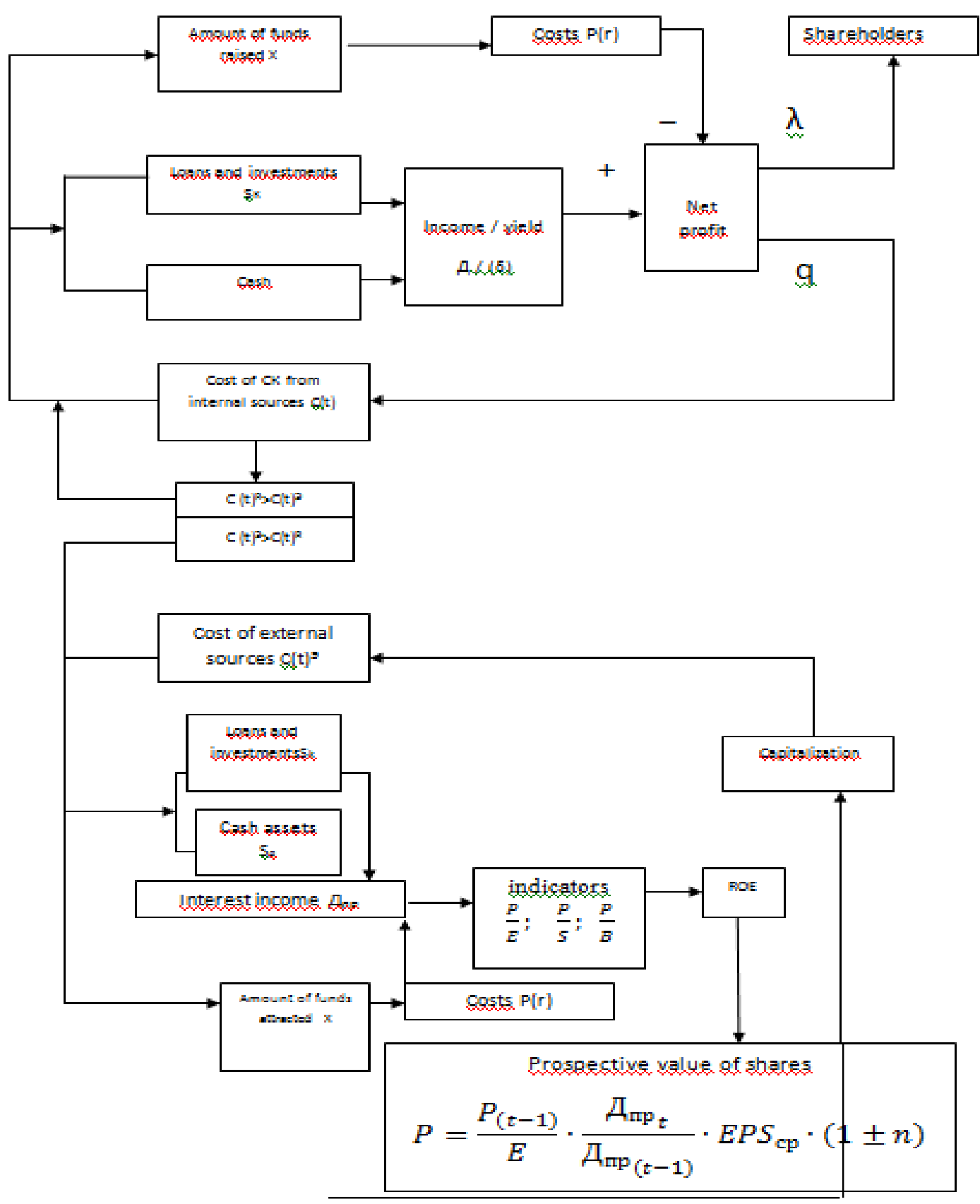

Figure 2. The Managing Mechanism of the Commercial Bank's Equity

Source: Compiled by the Authors.

Comparing the prospective return on equity calculated on the basis of reinvestment of profit (internal sources) (Table 2) and the perspective return on the bank's equity by increasing it by additional issue of own shares (Table 4), we can conclude that for all the banks studied, the issue of shares is the most effective method. Figure 2 proposes the managing mechanism of the commercial bank's equity, which helps choosing the most effective method of gains in equity: by reallocating part of the profit to the authorized capital (internal source) and through the secondary issue of its own shares (external source). The prospective return on the commercial bank's equity will be the main criterion for choosing the method of gains in equity.

\section{Discussion}

The formation and valuation of the bank's equity received wide coverage in scientific research. The vast majority of works are devoted to the study of the equity adequacy. In this connection, there is a need to conduct a comprehensive study of the issues of the commercial bank's equity, to find new approaches in its valuation. For example, Marichev S. A. [19] defines the bank's equity - as a set of liabilities formed during the organization and in the process of the bank's activity, Bagdalov R. Kh. [20] defines equity as the return on banking business, materialized in certain groups of the bank's equity that ensure its functioning as a specific enterprise. 
The concept of the bank's equity has many definitions. In our study, the emphasis is on valuating the productive nature of the bank's equity.

This study has led to the conclusion that there is a need to conduct a multilateral valuation of the bank's equity, which reveals its productive nature in terms of the effectiveness of its operating activities. It is necessary to valuate not only the aggregate of liabilities, but also the quality of bank assets.

To identify trends in operating activities, it is necessary to take into account the dynamic processes of the banking business and their impact on the return on equity, which justifies the application of BlackScholes dynamic option model to the valuation of the bank's own equity.

The model of the decision-making mechanism presented in the form of the objective function (17, 28) and constraints in the system of equations (29) allow determining the dynamics of changes in the bank's equity, revealing the reasons for the equity volatility and on the basis of these estimates developing effective management decisions in real time. Thus, the bank manager chooses the method of increasing the amount of equity by the criterion of return. It should be noted that it is possible to realize simultaneously two methods of gains in return, the necessary conditions in this case are not the negative return on equity $\mathrm{V}(\mathrm{t})$ in the option model $(17,28)$ and the excess of its return over the current return, determined by the formula (1).

\section{Conclusions}

\section{References}

1. Damodaran, A. (2011). Investitsionnaya otsenka: Instrumenty i metody otsenki lyubykh aktivov, pp.1344.

2. Sinky, Joseph (2007). Commercial Bank Financial Management in the Financial-Services Industry. Издательство: Al'pina Biznes Buks

3. Dahl, D. \& Spivey, M.F. (1996). The effects of declining capitalization on equity acquisition by commercial banks. Journal of Banking \& Finance, Volume 20, Issue 5, pp. 901-915. https://doi.org/10.1016/0378-4266(95)00031-3. 4. Ahmed, A.S. \& Takeda, C. (1995). Stock market valuation of gains and losses on commercial banks' investment securities. An empirical analysis. Journal of Accounting and Economics, Volume 20, Issue 2, pp. 207-225. https://doi.org/10.1016/0165-4101(95)00396-Z .

5. Rossia, S.P.S. \& Schwaiger, M.S. \& Winkler, G. (2009). How loan portfolio diversification affects risk, efficiency and capitalization: A managerial behavior model for Austrian banks. Journal of Banking \& Finance, Volume 33, Issue 12, pp. 2218-2226. https://doi.org/10.1016/j.jbankfin.2009.05.022 .

6. Glen, J. \& Camilo Mondragón-Vélez (2011). Business cycle effects on commercial bank loan portfolio performance in developing economies. Review of Development Finance, Volume 1,
The research carried out in the scientific article made it possible to draw a number of theoretical and practical conclusions, which are as follows:

- The classification of the main functions of the commercial bank's equity has been extended - it has been proposed to include the valuation function of equity in the main classification as an effectiveness indicator of managing the bank's equity (pp. 5-6);

- The application of Black-Scholes dynamic model to evaluate the return on the commercial bank's equity is justified (pp. 8-11);

- The parameters of Black-Scholes option model were modified to evaluate the prospective return on equity when it increased due to the allocation of profits in the authorized capital of the commercial bank (pp.11-15); - The most significant financial indicators of the commercial bank have been determined, which affect the change in the exchange shares value, which made it possible to identify dependencies in evaluating the future bank shares value and calculating the value target of the share (pp. 15-18);

- The model of the decision making mechanism for increasing the commercial bank's equity based on the secondary issue of its own shares (pp. 18 - 19);

- The mechanism for managing the commercial bank's equity, which includes valuating and analyzing methods for increasing the bank's equity, has been proposed (pp. 19 - 20).

\section{Acknowledgments}

The authors thank all participants of this research for their kind cooperation.

Issue $2, \quad$ pp. 150-165. https://doi.org/10.1016/j.rdf.2011.03.002.

7. Beloglazova, G.N, Krolivetskaya, L.P. (2008). Banking. Organization of the commercial bank. Moscow: Higher education, $278 \mathrm{p}$.

8. Lavrushin, O.I. (2012). Finansy i kredit: uchebnoye posobiye, p. 320.

9. Tosunyan G.A. The banking system of Russia http://www.ru-90.ru/node/1211/

10. Schooner, H. M. \& Taylor, M. W. (2010). Chapter 1 - The Changing Nature of Banks. Global Bank Regulation. Principles and Policies, pp. 1-17. https://doi.org/10.1016/B978-0-12641003-7.00003-9

11. Morsink, J. and Gordon, J. (2016). RUSSIAN FEDERATION FINANCIAL SYSTEM STABILITY ASSESSMENT. Prepared By Monetary and Capital Markets Department. IMF Country Report No. 16/231. https://www.imf.org/external/pubs/ft/scr/2016/cr 16231.pdf

12. Zayernyuk, V.M., Mukhomorova, I.V. \& Nazarova, Z.M.,.Leonova, V. P \& Egorova, E. N. (2016). Modern Banking Sector in Russia: Trends of Development, Control and Supervision. Indian Journal of Science and Technology, Vol. 9 (42), DOI: $10.17485 / \mathrm{ijst} / 2016 / \mathrm{v} 9 \mathrm{i} 42 / 104308$

13. Gorchakov, V. \& Alvarez, H. (2017). Russia Industry Research _ $\quad$ Banks. 
https://www.raexpert.eu/files/Industry_annual_re port_Banks_06.09.2017.pdf

14. Anzoategui, D. Soledad Martínez Pería, M, and Melecky, M. (2010). BANKING SECTOR COMPETITION IN RUSSIA. The World Bank Eastern Europe and Central Asia Finance and Private Sector Development Department \& Development Research Group. Finance and Private Sector Development Team. Policy Research Working Paper 5449.

15. CEE Banking Sector Report EE Banking Sector Report (June 2017). Banking Sector Convergence 4.0. Editor: Gunter Deuber. Raiffeisen Bank International AG, Vienna.

16. Korobova, G. G. (2015). Bankovskoe delo, 592.

17. Sorokina, M.G., and Khmaruk, V.V. (2012). Otsenka effektivnosti uvelicheniya sobstvennogo kapitala kommercheskogo banka za schet vnutrennikh istochnikov. Nauchnoinformatsionnyy zhurnal «Ekonomicheskiye nauki», 10 (83), pp. 168-171.

18. Limitovskiy, M.A. (2014). Investitsionnyye proyekty i real'nyye optsiony na razvivayushchikhsya rynkakh: uchebnoprakticheskoye posobiye, p. 486.

19. Marichev, S.A. (2004). Kapitalizatsiya rossiyskoy bankovskoy sistemy: problem i perspektivy rosta. Den'gi i kredit, 11, pp. 44-50. 20. Bagdalov, R. Kh. (2003). Sobstvennyy capital banka i upravleniye im: avtoreferat dissertatsii na soiskaniye uchenoystepeni kandidata ekonomicheskikh nauk, 28.

21. Sorokina, M.G., and Khmaruk, V.V. (2011). Otsenka effektivnosti uvelicheniya sobstvennogo kapitala kommercheskogo banka putem dopolnitel'noy emissii aktsiy. Vestnik Samarskogo gosudarstvennogo ekonomicheskogo universiteta, 11, pp. 78-83 